\title{
MINERAL ASSEMBLAGES AND GENESIS OF THE CU-AU EPITHERMAL DEPOSITS IN THE SOUTHERN PART OF THE PANAGUYRISHTE ORE DISTRICT, BULGARIA
}

\author{
Bogdanov K. ${ }^{1}$, Tsonev D. ${ }^{1}$, and Popov K. ${ }^{2}$ \\ 1 Department of Mineralogy, Petrology and Economic Geology, Sofia University, 15 Tsar \\ Osvoboditel Bd., 1504 Sofia, Bulgaria, kamen@gea.uni-sofia.bg, dtsonev@gea.uni-sofia.bg
}

2 University of Mining and Geology "St.I. Rilski",1700 Sofia, Bulgaria, kpopov@mgu.bg

\section{ABSTRACT}

Epithermal Cu-Au deposits hosted within volcanic rocks (Radka, Elshitsa, Krassen) are related to Late Cretaceous andesite-dacite volcanic terrain in the Panagyurishte ore district. The $\mathrm{Cu}-\mathrm{Au}$ ores are linked by a similar mineralogy and differ by the ratio of tennantite, bornite, enargite and discrete trace minerals of $\mathrm{Ga}, \mathrm{Ge}$, In and $\mathrm{Bi}$ (e.g., roquesite, germanite, betekhtinite, renierite, vinciennite, aikinite). Bi-Se-Te and Ga-Ge-In-Sn signature with pronounced Au-enrichment of the bornite rich ores is a characteristic feature underlying the increasing role of the $\mathrm{fS}_{2} / \mathrm{fO}_{2}$ control during the transition from IS tc HS environment. Formation of the epithermal Cu-Au deposits appears to have occurred during a single broad event of contemporaneous formation of epithermal and porphyry systems. The close connection between the volcano-plutonic structures facilitates the multistage and polycyclic character of their hydrothermal systems, the similar character of the epithermal ores and the mineral succession in Elshitsa, Radka and Krassen deposits. The $\delta^{34} \mathrm{~S}$ ratios in the sulphide minerals range from -6.7 to 4.0 , suggesting comparable magmatic sources for the epithermal mineralizing fluids and close link with porphyry environment.

\section{INTRODUCTION}

The Panagyurishte ore district is located in a $30 \times 50 \mathrm{~km}$ belt trending N-NW to S-SE, including the town of Panagyurishte in Central Srednogorie, Bulgaria (Fig.1). The district belongs to the Late Cretaceous Banat-Srednogorie metallogenic zone, part of the Alpine-Balkan-Carpathian-Dinaride (ABCD) belt (Heinrich \& Neubauer 2002). The Srednogorie part of the ABCD belt in Bulgaria, developed during the Mesozoic as a copper-rich, andesite-dominated island arc system (Fig. 1) that continues eastwards through Turkey to Iran (Jankovic 1977, Bogdanov 1987, Dabovski et al. 1991).

A series of volcanic rock-hosted sulphide ore deposits (e.g. Radka, Elshitsa and Krassen) related to Late Cretaceous andesite-dacite volcanic activity are located in the southern part of the Panagyurishte district ( $\mathrm{F} / \mathrm{g} .1)$. They are spatially associated with small porphyry copper ore deposits (Vlaikov Vruh, Tsar Assen, Petelovo) hosted by co-magmatic subvolcanic monzodiorite, granodiorite and quartz diorite porphyritic intrusions.

Two main types of ore bodies are characteristic of the volcanic rock-hosted sulphide deposits: early massive pyrite ore bodies and late $\mathrm{Cu}-\mathrm{Au}$ sulphide ore bodies. The massive structures of the early pyrite ores and the presence of pyrite laminations in the host dacite tuffs at Radka, Elshitsa and Krassen have been interpreted as possibly due to syngenetic VMS deposition coeval with dacitic volcanism (Bogdanov 1984, 1987, Bogdanov et al. 1997). However the VMS-style massive sulphide and porphyry copper deposits have been considered as incompatible ore types, characteristic of discrete tectono-magınatic settings (Sillitoe 1999). At the same time, characteristic features such as adularia-sericite and advanced argillic alteration styles, the steep fault-controlled ore bodies (including the early massive pyrite ore bodies), the abundance of enargite, bornite and chalcocite in the late $\mathrm{Cu}-\mathrm{Au}$ ores provide good reasons to regard these deposits as the analogues of enargitebearing massive sulphide deposits, positioned high and/or late in porphyry copper systems (Sillitoe et al. 1996). Such mineralizations have more recently been described as high (alunite-kaolinite) and 
low (adularia-sericite) sulphidation epithermal deposits (Hedenquist et al. 1996). This classification based on oxidation state of sulphur has more recently been expanded (Hedenquist et al. 2000) to include an intermediate sulphidation division that is affiliated with some high-sulphidation deposits in volcanic arcs, a distinctly different volcano tectonic setting from most low sulphidation deposits.

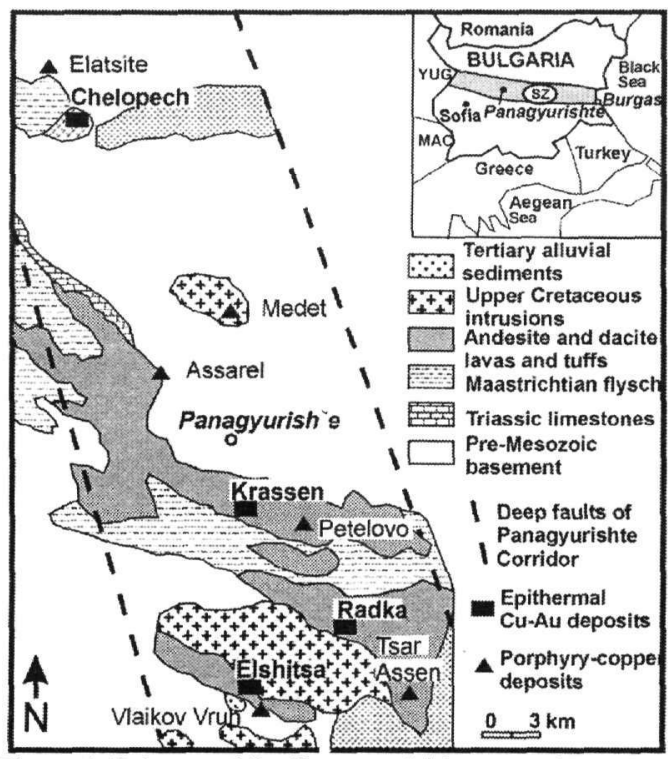

Figure 1. Scheme of the Panagyurishte ore region.

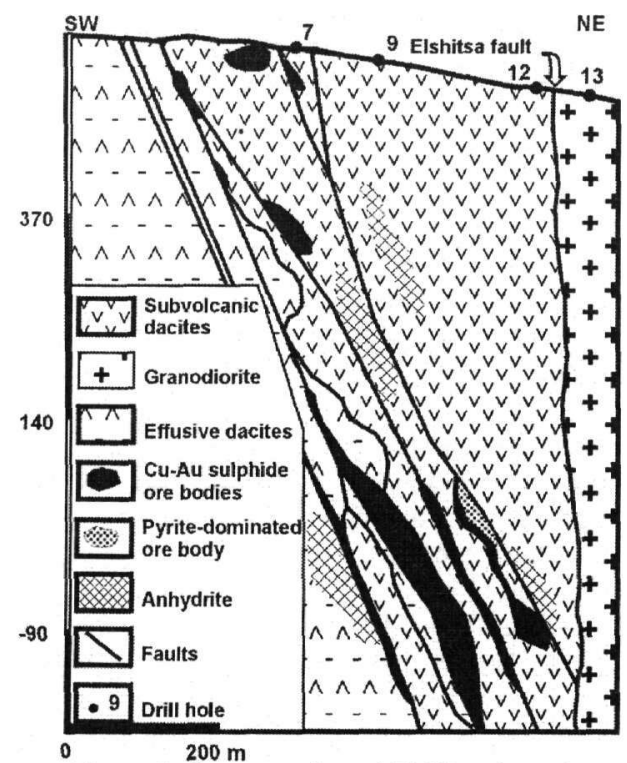

Figure 2. Cross-section of Elshitsa deposit.

\section{GEOLOGICAL SETTING}

The Panagyurishte ore district consists of pre- Upper Cretaceous metamorphic crystalline basement, Triassic sedimentary rocks, Turonian-Lower Senonian volcano-sedimentary rocks and Upper Senonian, Tertiary and Quaternary sedimentary rock complexes (Strashimirov \& Popov 2000, Popov et al. 2003). The pre-Upper Cretaceous rocks comprise metamorphic basement of Balkanide type (two-mic gneisses, mica schists and orthoamphibolites), granites of Paleozoic age, and Triassic limestones, sandstones and dolomites (Fig. 1). The basement rocks are overlain by Upper Cretaceous rocks, subdivided into three distinct volcanic and sedimentary complexes of Turonian, Lower Senonian and Upper Senonian age. The Turonian terrigenous complex is 150 to 400 $\mathrm{m}$ thick and consists of breccia, conglomerates, coal-bearing slates and sandstones, lying discordantly above the older rocks.

The Upper Cretaceous (Lower Senonian) volcano-plutonic complex is composed of calcalkaline to shoshonitic volcanic and rare sedimentary rocks and was formed in several extrusive centres. The volcano-plutonic complexes formation include: 1) volcanic; 2) plutonic; 3) sub-volcanic; and 4) dyke stages of magmatic activity. The Lower Senonian volcano-plutonic complex has a multistage and explosive character and hosts both porphyry and epithermal ores. The Upper Senonian postvolcanic sedimentary complex is represented by the Santonian-Campanian marlstones, sandstones and conglomerates as well as by the 500 to $700 \mathrm{~m}$ thick Campanian-Maastrichtian carbonaceous flysch. The Tertiary and Quaternary sediments consist of Paleogene conglomerates, Pliocene breccia and conglomerates, sandstones and clays; and Quaternary gravels, sands and clays covering part of the pre-Cenozoic sequence (Fig.1). Ages of the main magmatic stages using KJAr dating are as follows: volcanic (92-87Ma), plutonic (88-82Ma), sub-volcanic (88-74Ma) and dyke (74-67Ma) (Bogdanov 1987, Lilov \& Chipchakova 1999). Based on U-Pb zircon dating, Peytcheva et al. $(2001,2003)$ provided ages between $81.2+0.5 /-0.7$ and $86.62 \pm 0.02 \mathrm{Ma}$ for the Elshitsa granite and $86.11 \pm 0.23 \mathrm{Ma}$ for the Elshitsa subvolcanic dacites. ${ }^{40} \mathrm{Ar} /{ }^{39} \mathrm{Ar}$ amphibole age of $85.70 \pm$ $0.35 \mathrm{Ma}$ for the coarse-grained granodiorite of the Medet pluton was obtained by Handler et al. 
(2002). These age date; span of about $25 \mathrm{~m}$.y. suggesting that the magmatic activity was punctuated, changing character and relatively long lived.

\section{THE EPITHERMAL ORE DEPOSITS}

The Elshitsa ore deposit is situated close to the southern margin of the Elshitsa pluton (Fig. 1). The Elshitsa fault has a trend of 110 to $130^{\circ}$, dips steeply to the NE at 75 to $85^{\circ}$ (Figs. $1,2 \mathrm{~A}$ ), and is the main ore-controlling structure where it intersects the N-NW strike-slip faults (Bogdanov, 1987). Quartz-sericite (illite \pm smectite) and propylitic (albite-chlorite-epidote \pm calcite) styles of alteration are the most $\mathrm{c}$ गmmon in the andesites and dacites at Elshitsa. Adularia alterations are rarely observed, while the advanced argillic and quartz-diaspore alteration have been observed in the footwall of the massive pyrite ores (Radonova \& Velinov, 1974; Strashimirov \& Popov 2000). Two compositionally distinct types of ore can be recognized (Fig. 2): ores dominated by massive pyrite, and pyrite-chalcopyrite with minor galena, sphalerite and gold. The early massive pyrite ore bodies were formed in the eastern part, followed by later $\mathrm{Cu}-\mathrm{Au}$ sulphide ore bodies in the central and western parts of the deposit (Fig. 2). Rare galena-sphalerite veinlets also occur, cutting the pyrite-chalcopyrite ore bodies. Lenticular and lens-like ore bodies are characteristic of the upper parts, while the sheet-like disseminated, vein and stringer ore bodies are commonly observed in the deeper parts of the depusit. The thickness of the ore bodies varies from several meters up to $50 \mathrm{~m}$; the length from several meters up to $250-300 \mathrm{~m}$ horizontally and up to $500 \mathrm{~m}$ vertically. The sulphide mineralization in the inner parts of ore bodies is predominantly massive and changes gradationally from veinlet to disseminated on the periphery.

The Radka ore deposit is located within the northern part of the Elshitsa volcano-intrusive structure, $3 \mathrm{~km}$ S-SE of the village of Popintsi (Fig. 3A). The andesite and dacite lava flows, agglomerate and lapilli tuffs have an W-NW strike and dip $25-45^{\circ} \mathrm{N}-\mathrm{NE}$. The effusive rocks are intersected by several sub-volcanic dacite dykes with varying thickness (Fig. 3A). The sub-vertical dykelike granodiorite porphyry intrusion was found at depth by drilling and mining works (Fig. $3 A$ ). The E-NE, NW and NE faults played a considerable role in increasing of the permeability of the host andesite volcanic rocks. The ore bodies are distributed in a complicated $\mathrm{V}$-shaped block, bordered by a group of conjugate faults (Fig. 3A).

Quartz-sericite (illite \pm smectite) and advanced argillic alteration affect the inner parts of the effusive rocks close to the ore bodies, while in the outer parts the propylitic alteration predominates (Radonova and Velinov, 1974). The pyrite and Cu-Au sulphide (copper-pyrite) ore bodies occur as columnar, lens-like, or pipe-like shapes. Mainly the fault zone with a W-NW direction and dip to the north controls their position. Ore shoots of massive pyrite-chalcopyrite and bornite ores with isometric or irregular shapes, fiameters from 2 to $30 \mathrm{~m}$ and $10-50 \mathrm{~m}$ long in depth are characteristic for Radka. Low-grade typically veinlet-disseminated ores also occurred and were mined by open pit close to the surface. The ore bodies crosscut the bedding of the andesite and dacite tuffs and are rarely sub-parallel. According to the mineral composition, massive pyrite-dominant and $\mathrm{Cu}-\mathrm{Au}-$ sulphide (pyrite-chalcopyrite, bornite-chalcopyrite-chalcocite-tennantite and galena-sphaleritechalcopyrite) ore bodies can be recognized (Fig. 3A).

The Krassen ore deposit is located within an 80 to $100 \mathrm{~m}$ thick fault zone, limited by two subparallel fault arms trending 110 to $115^{\circ}$ and dipping 50 to $65^{\circ}$ to NE (Fig. 3B). The pyrite-enargite dominated mineralization is tectonically controlled by a series of sub-parallel zones of tectonic breccias that host the py rite-enargite ore bodies (Fig. 3B).

The Krassen deposit represents a pipe-like tectonic breccia zone affected by intense quartzsericite (illite \pm smectite) and advanced argillic quartz-kaolinite (dickite) alteration (Strashimirov \& Popov 2000, Bogdanov and Popov 2003), in which individual lens-like and columnar ore bodies are located (Fig. 3B). This zone has an ellipse-like section, 300 to $100 \mathrm{~m}$ in length, a dip of about $50^{\circ}$ to $\mathrm{NE}$ and can be traced intermittently to a depth of $700 \mathrm{~m}$. Most of the ore bodies are lenticular in shape (Fig. 3B). Pyrite, chalcopyrite, covellite and bornite are widespread, but the enargite is most abundant ore mineral in the Krassen deposit (Fig. 4D), placing the deposit firmly within the high sulphidation style of mineralization (Hedenquist et al. 1996, 2000). Enargite-chalcopyrite-bornite mineralization is domini.nt in the western part of the deposit. A series of massive pyrite-enargite 
lenses, containing subordinate chalcopyrite and bornite, are characteristic of the central part of the deposit. Low-grade vein pyrite is common in the eastern part of Krassen deposit.

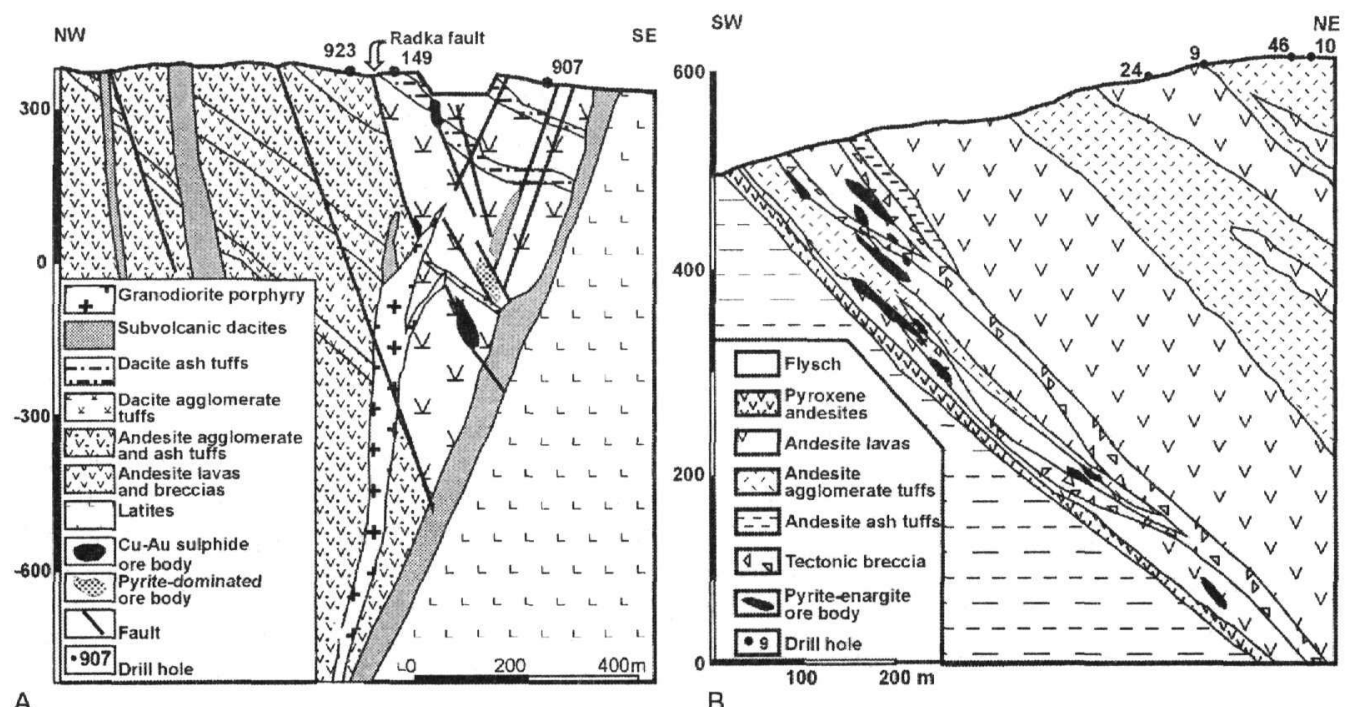

A

B

Figure 3. Cross-sections of Radka (A) and Krassen (B) Cu-Au epithermal deposits.

\section{MINERAL ASSEMBLAGES}

For the last 70 years the gold-bearing mineral assemblages and mineralization processes of these epithermal deposits now established in the subject of the paper have been studied by many researchers (Dimitrov 1i60, Tsonev 1974, Bogdanov 1980, 1987, Bogdanov et al. 1997, Strashimirov \& Popov 2000, Kouzmanov 2001, Bogdanov \& Popov 2003 and many others).

The mineral assemblages of the ores at the Elshitsa, Radka and Krassen are similar and differ only by the amount of tennantite, bornite, enargite and trace minerals of $\mathrm{Ga}, \mathrm{Ge}, \mathrm{In}, \mathrm{Bi}, \mathrm{Sn}, \mathrm{Se}$ and Te that are present. The ore mineralogy is dominated by pyrite and chalcopyrite (Elshitsa), pyrite, chalcopyrite and bornite (Radka) and pyrite and enargite (Krassen), which form more than $90 \%$ of the sulphide volume of the main ore bodies. The parageneses in the Elshitsa, Radka and Krassen deposits could be related to eight mineral assemblages: Early (1) Pyrite-quartz assemblage; Main (2) Chalcopyrite-pyrite; (3) Enargite-pyrite; (4) Bornite-tennantite and; (5) Galena-sphaleritechalcopyrite; Late (6) Quartz-pyrite (7) Pyrite-marcasite and (8) Anhydrite-gypsum assemblages (Fig. 4, 5 and 6).

In Elshitsa deposit the early mineral assemblage is dominated mainly by pyrite with atoll-like, colloform and zonal textures (Fig. 4B) associated with quartz and rare 1-20 $\mu$ m relicts of rutile, cassiterite and titano-magnetite. The colloform pyrite contains $1-3 \mathrm{ppm} \mathrm{Au}$ and $0.24-1.67 \mathrm{wt} \% \mathrm{As}$ (Todorov 1991, Bogdanov et al. 1997). Clastic deformation of pyrite is widespread with quartz, chalcopyrite (Fig. 4C), galena and sphalerite breccia fillings.

Except for pyrite, chalcopyrite is the dominant sulphide in the main mineral assemblages (Table 2) and occurs as massive lenses and veinlets. Tennantite-tetrahedrite mineral series, galena and sphalerite are subordinate. NAA data (Todorov 1991) indicate Au content at the range of 3.77-14.70 ppm in pyrite and 0.24-1.24 ppm in chalcopyrite. Enargite occurs as rare 5-50 $\mathrm{mm}$ irregular shaped grains associated with pyrite, tennantite and sphalerite only in the upper horizons of Elshitsa suggesting only a local importance of the early HS fluids.

The galena-sphalerite-chalcopyrite mineral assemblage is characterized by the deposition of galena, sphalerite, pyrite, bornite, covellite and chalcopyrite, as well as tennantite-tetrahedrite series minerals. All these minerals are carriers of $\mathrm{Au}$ and $\mathrm{Ag}$. Both tennantite and galena contains $\mathrm{Te}$ minerals observed as rare sub- $5 \mu \mathrm{m}$ inclusions identified as stoichiometric altaite $\mathrm{Pb}_{1.0} \mathrm{Te}_{1.0} \mathrm{Se}_{0.02}$ and hessite $\mathrm{Ag}_{2} .0 \mathrm{Te}_{1.0}$. The bismuth minerals in Elshitsa are represented by Se-bearing aikinite with 
composition $\left(\mathrm{Cu}_{0.95} \mathrm{Fe}_{0.01}\right)_{0.96} \mathrm{~Pb}_{1.12} \mathrm{Bi}_{0.90}\left(\mathrm{~S}_{2.91} \mathrm{Se}_{0.10}\right)_{3.01}$, native $\mathrm{Bi}$ and tetradymite, which are associated with the opaque minerals of the chalcopyrite-pyrite assemblage. There is a clear record of crosscutting and replacement relationships between the early pyrite-dominated ores and later copper-rich mineralization (iig. 4C). Both are crosscut by the latest quartz-pyrite (Fig. 4F) and anhydrite veins.

The late mineral asssemblages consists of quartz-pyrite and anhydrite-gypsum veins crosscutting and replacing minerals assemblages from earlier stages. The widespread late quartz-pyrite assemblage is found as W-NW trending veins of milky quartz ranging from mere stringers up to 1-5 $\mathrm{cm}$ wide (Fig. 4F) and up to $50 \mathrm{~m}$ long, with $\{100\}$ and $\{210\}$ pyrite with up to $2-3 \mathrm{~cm}$ edge length. The late anhydrite-gypsum mineral assemblage is represented by anhydrite, gypsum and barite veins and lenses replacing the sulphide ore. Marcasite in assemblage with pyrite implies that the hydrothermal conditions were quite acid and lower temperature in the late mineral assemblages.

Native gold has been found in all eight mineral assemblages, but it is most abundant in galenasphalerite-chalcopyrite assemblage, where it occurs as microscopic flattened, elongate, or irregular single grains that rare exceed $0.2 \mathrm{~mm}$ in size (Bogdanov et al. 1997).

The early pyrite assemblage in Radka deposit is represented mainly by colloform-textured pyrite, containing $0.80-4.17 \mathrm{ppm}$ Au as indicated by NAA data (Todorov, 1991), due to dispersed particles of sub-microscopic gold. Chalcopyrite, bornite, covellite and tennantite-tetrahedrite are dominant minerals in the main assemblages and occur as intergrown massive aggregates, commonly containing $10-80 \mu \mathrm{m}$ blebs of goldfieldite that seems to be the main Te carrier. As an important gold carrier bornite typically contains $8.10-41.80 \mathrm{ppm}$ Au as indicated by NAA data of Todorov (1991). Enargite is rare and occurs only in the upper levels at Radka. Exotic rare $\mathrm{Ga}, \mathrm{Ge}$, In and $\mathrm{Sn}$ minerals occur as 1-10 $\mu \mathrm{m}$ inclusions within bornite, tennantite, galena and sphalerite, and as a rule accompany elevated Au concentrations in the HS-epithermal ores. Microanalytical data confirmed the following trace minerals: roquesite $\left(\mathrm{Cu}_{1.11} \mathrm{Zn}_{0.05} \mathrm{Fe}_{0.01}\right)_{1.17} \mathrm{n}_{1.0} \mathrm{~S}_{2.08}$, gallite

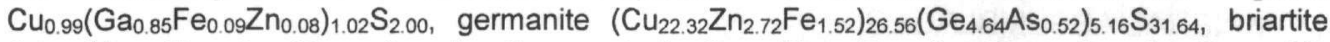
$\mathrm{Cu}_{1.98}\left(\mathrm{Zn}_{0.68} \mathrm{Fe}_{0.38}\right)_{1.06}\left(\mathrm{Ge}_{1.01} \mathrm{As}_{0.01}\right)_{1.02} \mathrm{~S}_{3.96}$, renierite $\mathrm{Cu}_{9.94}\left(\mathrm{Fe}_{3.67} \mathrm{Zn}_{0.40}\right)_{4.07}\left(\mathrm{Ge}_{1.87} \mathrm{As}_{0.13}\right)_{2.00} \mathrm{~S}_{15.99}$. Micron-sized inclusions of $\mathrm{Sn}$ minerals such as vinciennite $\mathrm{Cu}_{10.16} \mathrm{Fe}_{3.90} \mathrm{Sn}_{1.00} \mathrm{As}_{0.94} \mathrm{~S}_{15.98}$, stannite $\mathrm{Cu}_{2.02} \mathrm{Fe}_{1.05} \mathrm{Sn}_{1.0} \mathrm{~S}_{4.11}$, kesterite $\mathrm{Cu}_{2.05}\left(\mathrm{Zn}_{0.74} \mathrm{Fe}_{0.19}\right)_{0.93} \mathrm{Sn}_{0.93} \mathrm{~S}_{4.06}$, kiddcreekite $\mathrm{Cu}_{6.01} \mathrm{Sn}_{1.00} \mathrm{~W}_{1.00} \mathrm{~S}_{7.98}$, and buckhornite $\mathrm{Au}_{0.77} \mathrm{Db}_{1.92}\left(\mathrm{Bi}_{0.60} \mathrm{Fe}_{0.47}\right)_{1.07} \mathrm{Te}_{1.92} \mathrm{~S}_{3.33}$ that have been identified in the bornitetennantite and the galena-sphalerite-chalcopyrite assemblages, suggest a close link between epithermal and porphyry environment.

Bismuth minerals in Radka are represented by $5-10 \mu \mathrm{m}$ lamellar inclusions of aikinitebismuthinite series in addition to wittichenite (Bogdanov et al. 1997, Kouzmanov 2001, Bogdanov \& Popov 2003) and the rare Bi-telluride, tsumoite $\mathrm{Bi}_{1.0} \mathrm{Cu}_{0.03} \mathrm{Te}_{1.06}$, found in association with the minerals of the chalcopyrite-pyrite assemblage. Bi minerals are locally abundant and associated with gold and chalcopyrite, often indicating Au-enrichment.

The late assemblages consist of quartz-pyrite and anhydrite gypsum veins, which crosscut and replace minerals fr $\mathrm{m}$ the earlier mineralization stages. The anhydrite veins and lenses are abundant in the deeper horizons of Radka deposit while gypsum is more common at upper levels.

Native gold (Fig. 4E) is more abundant in the enargite-pyrite, bornite-tennantite and galenasphalerite-chalcopyrite assemblages. The gold is $0.1-100 \mu \mathrm{m}$ in size and commonly associated with bornite, tennantite, chalcopyrite, sphalerite and galena. Macroscopic (>100 $\mu \mathrm{m})$ gold and electrum grains and aggregates of gold up to $5 \mathrm{~mm}$ are rarely found in the bornite-tennantite-chalcocite oresin Radka deposit (Fig. 4G). Electrum and gold occur as blebs or irregular particles in the sulphide minerals, or along grain boundaries. The elongate, isometric and ellipse-like gold grains are most commonly found in assemblages with enargite, bornite, tennantite, chalcopyrite, galena and chalcocite. Anhedral anc' sharp-edged gold grains, or short veinlets are also present in some cases. Native silver was found in wiry forms (Fig. $4 \mathrm{H}$ ), as thin native silver veinlets, not exceeding $0.5 \mathrm{~mm}$ in width and up to $5 \mathrm{~cm}$ in length and as irregular inclusions in bornite. In Radka, the silver is $\mathrm{Hg}$ bearing. The gold grade in the primary ore is $1-3 \mathrm{~g} / \mathrm{t}$, rarely up to $8-10 \mathrm{~g} / \mathrm{t}$, and has been extracted as a by-product from both the pyrite and copper concentrates.

The ore mineralization in Krassen deposit is comparable to Radka, but enargite is much more abundant and characteristic (Fig. 4D) for individual orebodies at Krassen. The early assemblage is represented mainly by colloform-textured pyrite with up to $16.10 \mathrm{ppm}$ Au (Todorov 1991), which 


\begin{tabular}{|c|c|c|}
\hline $\begin{array}{l}\text { Early } \\
\text { assemblage } \\
\text { Minerals }\end{array}$ & Pyrite-quartz & \\
\hline $\begin{array}{l}\text { Quartz } \\
\text { Cassiterite } \\
\text { Ti-magnetite } \\
\text { Rutile } \\
\text { Anatase } \\
\text { Pyrite } \\
\text { Gold } \\
\end{array}$ & 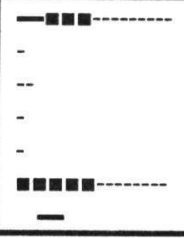 & \\
\hline $\begin{array}{l}\text { Main } \\
\text { assem- } \\
\text { blages } \\
\text { Minerals }\end{array}$ & $\begin{array}{l}\text { Chalcopyrite } \\
\text { - pyrite }\end{array}$ & $\begin{array}{l}\text { Enargite- } \\
\text { pyrite }\end{array}$ \\
\hline $\begin{array}{l}\text { Quartz } \\
\text { Pyrite } \\
\text { Gold } \\
\text { Electrum } \\
\text { Chalcopyrite } \\
\text { Enargite } \\
\text { Luzonite } \\
\text { Wittichenite } \\
\text { Emplectite } \\
\text { Friedrichite } \\
\text { Hammarite } \\
\text { Aikinite } \\
\text { Tetradymite } \\
\text { Buckhornite } \\
\text { Tsumoite } \\
\text { Bismuth } \\
\text { Micharaite } \\
\text { Tennantite }\end{array}$ & 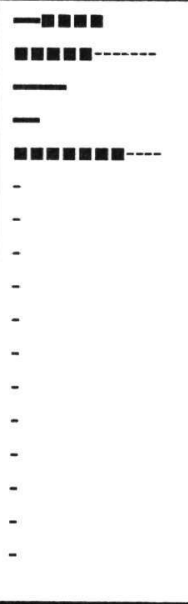 & 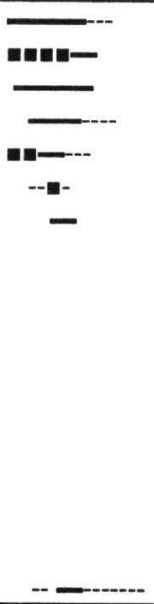 \\
\hline
\end{tabular}
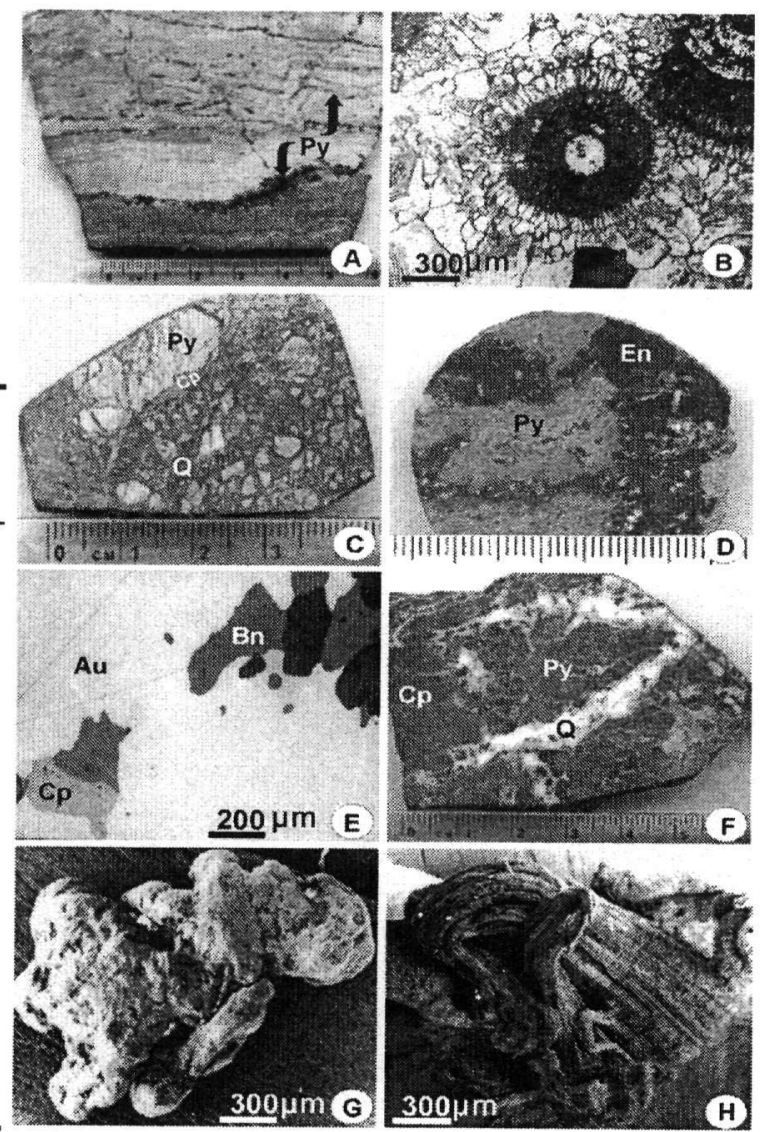

Figure 4. Early and main mineral assemblages: A- dacite tuff from Krassen with pyrite (Py) lamination (scale in $\mathrm{cm}$ ); B- zonal texture of , olloform pyrite (Early pyrite-quartz assemblage) from Elshitsa deposit; $C$-pyrite (Py) breccia replaced and crosscutted by chalcopyrite $(\mathrm{Cp})$ and quartz $(\mathrm{Q})$ from the chalcopyrite-pyrite assemblage; D- Early pyrite (Py) replaced by enargite (En) from Krassen deposit (scale in $\mathrm{cm}$ ); E- gold (Au) in assemblage with bornite $(B n)$ and chalcopyrite $(C p)$, Radka deposit; F-early pyrite (Py) and (Cp) chalcopyrite chalcopyritepyrite assemblage) crosscutted and replaced by the late vein quartz $(Q)$, (scale in $\mathrm{cm}) ; \quad G$-gold extracted from bornite-chalcopyrite ore, Radka deposit, SEM; H - native silver from Radka deposit, SEM.
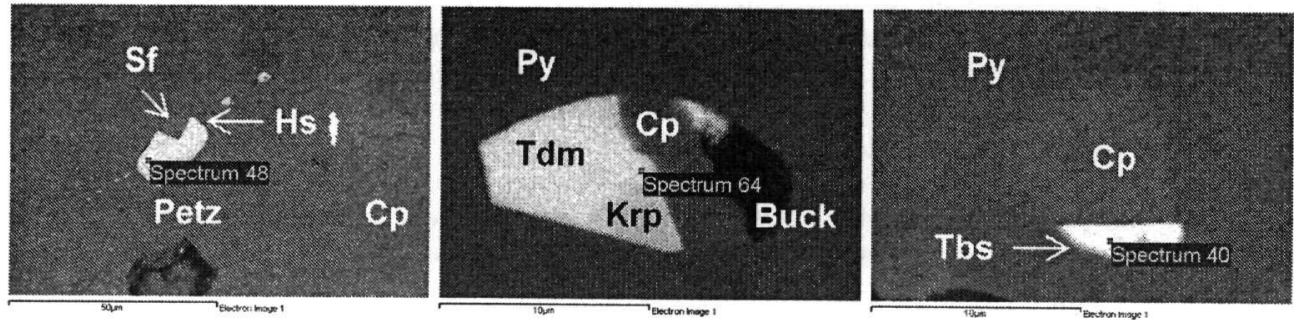

Figure 5. Trace minerals in Radka Cu-Au epithermal deposit (Hs-hessite; Petz-petzite; Tdm-tetradymite; Krpkrupkaite; Buck-buckhornite; Tbs-tellurobismutite).

occurs as anhedral disseminations and aggregates. Enargite $\mathrm{Cu}_{3.14}\left(\mathrm{As}_{1.0} \mathrm{Sb}_{0.02}\right)_{1.02}\left(\mathrm{~S}_{3.71} \mathrm{Se}_{0.01}\right)_{3.72}$ is very abundant and is observed replacing the early pyrite, or in association with chalcopyrite, bornite and chalcocite in the main mineral assemblages (Fig. 6). The enargite-rich ore bodies are also gold rich with grades up to $6-8 \mathrm{~g} / \mathrm{t}$. Aikinite with close to the stoichiometric composition 


\begin{tabular}{|c|c|c|c|c|c|c|}
\hline $\begin{array}{l}\text { Main } \\
\text { assemblages } \\
\text { Minerals }\end{array}$ & $\begin{array}{l}\text { Bornite- } \\
\text { tennantite }\end{array}$ & $\begin{array}{l}\text { Galena- } \\
\text { sphalerite- } \\
\text { chalcopyrite }\end{array}$ & $\begin{array}{l}\text { Late } \\
\text { assemblages } \\
\text { Minerals }\end{array}$ & $\begin{array}{l}\text { Quartz- } \\
\text { pyrite }\end{array}$ & $\begin{array}{l}\text { Pyrite- } \\
\text { marcasite }\end{array}$ & $\begin{array}{l}\text { Anhydrite- } \\
\text { gypsum }\end{array}$ \\
\hline $\begin{array}{l}\text { Quartz } \\
\text { Pyrite } \\
\text { Gold } \\
\text { Electrum } \\
\text { Chalcopyrite } \\
\text { Enargite } \\
\text { Tennantite } \\
\text { Bornite } \\
\text { Idaite } \\
\text { Renierite } \\
\text { Germanite } \\
\text { Vinciennite } \\
\text { Stannite } \\
\text { Briartite } \\
\text { Kesterite } \\
\text { Colusite } \\
\text { Digenite } \\
\text { Goldfieldite } \\
\text { Chalcocite } \\
\text { Tellurium } \\
\text { Altaite } \\
\text { Sulvanite } \\
\text { As-sulvanite } \\
\text { Tetrahedrite } \\
\text { Gallite } \\
\text { Roquesite } \\
\text { Sphalerite } \\
\text { Galena } \\
\text { Silver } \\
\text { Betekhtinite } \\
\text { Petzite } \\
\text { Hessite } \\
\text { Covellite }\end{array}$ & 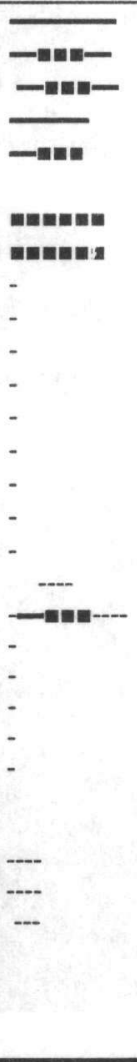 & 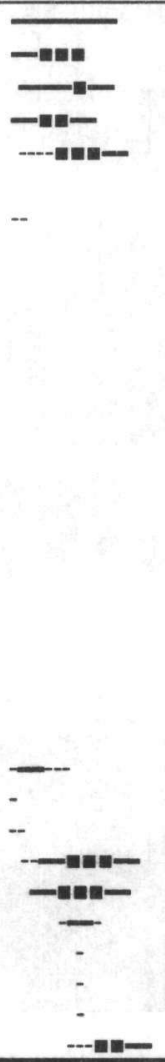 & $\begin{array}{l}\text { Quartz } \\
\text { Pyrite } \\
\text { Gold } \\
\text { Electrum } \\
\text { Chalcopyrite } \\
\text { Sphalerite } \\
\text { Galena } \\
\text { Silver } \\
\text { Marcasite } \\
\text { Calcite } \\
\text { Barite } \\
\text { Anhydrite } \\
\text { Gypsum } \\
\text { Mordenite } \\
\text { Heulandite } \\
\text { Laumontite } \\
\text { Stilbite }\end{array}$ & $\begin{array}{l}\text { guman } \\
\text { - }\end{array}$ & $\begin{array}{l}\overline{-} \\
- \\
-1 \times-\end{array}$ & 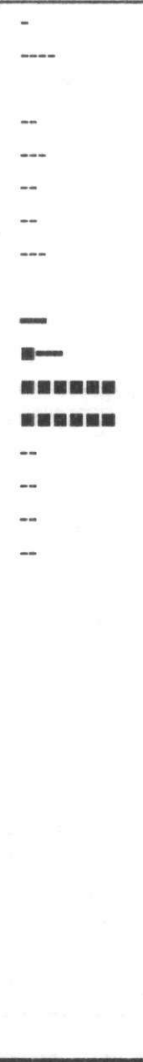 \\
\hline
\end{tabular}

Figure 6. Main and late mineral assemblages.

$\mathrm{Cu}_{1.0}\left(\mathrm{~Pb}_{1.04} \mathrm{Ag}_{0.01}\right)_{105}\left(\mathrm{Bi}_{1.04} \mathrm{As}_{0.03}\right)_{1.07} \mathrm{~S}_{3.08}$ was identified as sub $10 \mu \mathrm{m}$ lamellar inclusions in chalcopyrite and seems to be the most common Bi phase in the all three deposits. Late quartz-pyrite vein assemblage in Kras sen is not as abundant as compared to the Radka and Elshitsa deposits.

Gold in the early massive pyrite in Elshitsa, Radka and Krassen is sub-microscopic in size (< $0.1 \mu \mathrm{m}$ ) i.e., so-called "invisible" gold (Bogdanov et al. 1997). The deformation and recrystallization of the ore bodies and overprinting of the early sulphide assemblages by later stages caused Au and $\mathrm{Ag}$ migration to cracks and grain boundaries of the sulphide minerals. As a result of these processes, the native gold and electrum grain size increases from sub-microscopic $(<0.1 \mu \mathrm{m})$ in the early colloform pyrite to microscopic $(0.1-100 \mu \mathrm{m})$ and macroscopic $(>100 \mu \mathrm{m})$ in the late goldsulphide assemblages (Bogdanov et al. 1997). The electrum fineness in individual grains varies between 764 and 998 , as estimated by 126 microprobe analyses, characteristic for the epithermal class of mineral deposi:s (Morrison et al. 1991). $\mathrm{Cu}, \mathrm{Te}, \mathrm{Sb}$ and $\mathrm{Bi}$ are the most common trace elements in gold and electrum in Elshitsa, Radka and Krassen. Massive pyrite and pyrite- veinlet and disseminated ore bodies are poor in gold and other precious metals, as compared to the ore bodies with more complex mineral compositicns. The latter are rich in enargite, chalcopyrite, chalcocite and bornite, and are also important $\mathrm{Ga}, \mathrm{Ge}, \mathrm{Se}$ and Te carriers. 


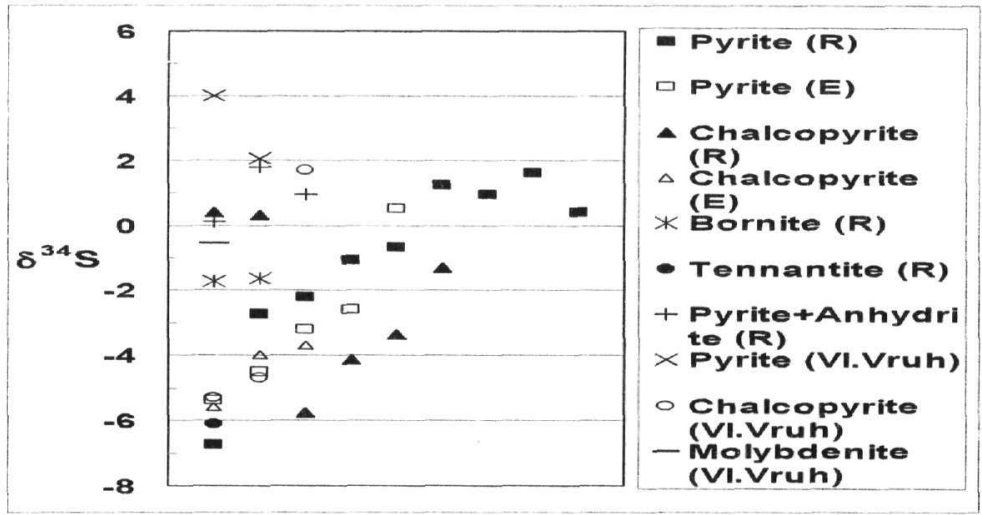

Figure 7. Sulphur isotope ratios in Radka (R) and Elshitsa (E) epithermal deposits and Vlaikov Vruh porphyrycopper deposit (data by Angelkov 1974, Velinov et al. 1978, Kouzmanov 2001).

\section{ORE GENESIS}

The Cu-Au sulphide ores are considered to be of hydrothermal and replacement origin (Dimitrov 1960, Tsonev 1974, Bogdanov 1984, 1987, Bogdanov et al. 1997, Kouzmanov 2001, Bogdanov and Popov 2003). They formed later than the pyrite bodies following intrusion of the sub-volcanic rhyodacites, replacing tie volcanic dacites, andesites and the associated pyroclastites and rhyodacite dykes. The late quartz-pyrite vein (Fig. 4F) and anhydrite-gypsum mineral assemblages are characteristic for the Elshitsa, Radka and Krassen as well as for the closely associated porphyry copper deposits (Fig. 1) suggesting a common source and close link between the individual porphyry and epithermal systems.

Based on existing data, the formation of the Cu-Au epithermal deposits could be integrated into a single broad event of contemporaneous formation of epithermal and porphyry systems related to and surrounding magmatic centres, including: 1 . Formation of early massive pyrite ores towards the end of the dacite volcanism. 2. Contemporaneous formation of the epithermal Cu-Au mineralization in the upper parts of thə epithermal-porphyry systems. 3. Formation of the late quartz-pyrite and anhydrite veins characteristic of both epithermal (Elshitsa, Radka and Krassen) and porphyrycopper (Vlaikov Vruh, Tsar Assen, Petelovo) deposits (Fig. 1).

According to fluid inclusion studies (Bogdanov 1987, Strashimirov et al. 2002, Kouzmanov 2001 , Tarkian et al. 2003) there is evidence for high salinity (28-64\% NaCl eq) and low salinity (2$6 \% \mathrm{NaCl}$ eq) fluids being present over the life of the hydrothermal systems. Hot $\left(325-379^{\circ} \mathrm{C}\right)$ and saline fluid (up to $64 \% \mathrm{NaCl}$ eq) is characteristic of the porphyry environment in the Panagyurishte district. In contrast, liquid-rich, medium to high temperature $\left(260-310^{\circ} \mathrm{C}\right)$ and more dilute $(4.7-5.9 \%$ $\mathrm{NaCl}$ eq) fluid that is typical of the Radka, Krassen and Elshitsa epithermal systems, transported considerable amounts of $\mathrm{Cu}, \mathrm{As}, \mathrm{Fe}$ and $\mathrm{Au}$. The successive hydrothermal phases of the discrete evolving volcano-plutonic systems precipitated chalcopyrite and the high sulphidation ore assemblage consisting of enargite, chalcocite and gold minerals in the Krassen deposit. Rare remnants of enargite, indicative of localized high-sulphidation conditions are preserved in the Elshitsa intermediate-sulphidation epithermal system, whereas Radka represents a transitional epithermal system with an intermediate to local high sulphidation style of ore mineralization. Enargite in the leached residual quartz zones is more abundant here compared to Elshitsa. Anhydrite veins formed as temperature waned in the late stages of three systems.

Recrystallization of the sulphide minerals suggest tectonic and hydrothermal ore remobilisation during the evolution of $\in$ pithermal and porphyry systems in accordance with the similar $\delta^{34} S$ values for the main sulphide minerals (Fig. 7) in Radka $\left(\delta^{34} S=-6.7\right.$ to -1.8$)$ and Elshitsa $\left(\delta^{34} S=-5.6\right.$ to +0.5$)$ epithermal deposits and for Vlaikov Vruh $\left(\delta^{34} S=-5.3\right.$ to +4.0$)$ porphyry copper deposit, indicating a magmatic source for sulphur. Comparison of the $\mathrm{Pb}$ isotope values of the main sulphide minerals $\left({ }^{206} \mathrm{~Pb} /{ }^{204} \mathrm{~Pb}=18.49-18.76 ;{ }^{207} \mathrm{~Pb} /{ }^{204} \mathrm{~Pb}=15.61-15.64 ;{ }^{208} \mathrm{~Pb} /{ }^{204} \mathrm{~Pb}=38.53-38.80\right)$ from Elshitsa, Radka 
and Vlaikov Vruh deposits with those of the Elshitsa granite $\left({ }^{206} \mathrm{~Pb} /{ }^{204} \mathrm{~Pb}=18.56-18.57\right.$; $\left.{ }^{207} \mathrm{~Pb} /{ }^{204} \mathrm{~Pb}=15.63-15.65 ;{ }^{208} \mathrm{~Pb} /{ }^{204} \mathrm{~Pb}=38.60-38.66\right)$ and the porphyry granodiorite of Vlaikov Vruh $\left({ }^{206} \mathrm{~Pb} /{ }^{204} \mathrm{~Pb}=18.61-18.77 ;{ }^{207} \mathrm{~Pb} /{ }^{204} \mathrm{~Pb}=15.62-15.66 ;{ }^{208} \mathrm{~Pb} /{ }^{204} \mathrm{~Pb}=38.61-38.82\right)$ suggest that the latter two were sources of the metals (Amov et al. 1974, Kouzmanov 2001). The ${ }^{87} \mathrm{Sr} /{ }^{86} \mathrm{Sr}$ ratios of anhydrite, gypsum, barite and calcite from Radka and Elshitsa epithermal deposits and Vlaikov Vruh porphyry copper deposit reported by Kouzmanov (2001) are between 0.7058 and 0.7072 , suggesting some mixing of strontium from the dacitic host rocks $\left({ }^{87} \mathrm{Sr} /{ }^{86} \mathrm{Sr}=0.7058-0.7061\right)$ and ${ }^{87} \mathrm{Sr}$ enriched basement rocks $\left({ }^{87} \mathrm{Sr} /{ }^{86} \mathrm{Sr}=0.7085-0.7154\right)$.

Andesite-dominated magmatic activity in the Panagyurishte structural corridor (Fig. 1) has a life span from Turonian to Maastrichtian that is about $25 \mathrm{Ma}$, while the formation of the porphyryepithermal systems of Eishitsa-Vlaikov Vruh, Radka-Tsar Assen, and Krassen-Petelovo (Fig. 1) appears limited to a narrower time interval of 1-5 m.y. (Lilov and Chipchakova 1999, Peytcheva et al. $2001,2003)$. The recent Re-Os dating of molybdenite $(82.1 \pm 0.6 \mathrm{Ma})$ from Vlaikov Vruh (Kouzmanov 2001) and U-Pb zircon data $(81.2+0.5 /-0.7 \mathrm{Ma}$ and $82.3 \pm 0.5 \mathrm{Ma}$ ) for the Elshitsa granite (Peytcheva et al. 2003) indicate a possible narrow interval of formation for the linked epithermal and porphyry deposits.

\section{CONCLUSIONS}

Epithermal deposits of intermediate (Elshitsa) and intermediate to local high (Radka, Krassen) sulphidation style of ores and porphyry copper deposits evolved in close proximity within three individual volcano-plutonic centers (Elshitsa-Vlaikov Vruh, Radka-Tsar Assen, and Krassen-Petelovo). The close connection between the andesite-granodiorite volcano-plutonic structures facilitates the multistage and polycyclic character of their hydrothermal systems. The similar character of the epithermal ores and the mineral assemblages in Elshitsa, Radka and Krassen deposits and their discrete trace mineralogy reflects the varying $\mathrm{fS}_{2} / \mathrm{fO}_{2}$ states in the individual epithermal deposits, depending on their depth of formation, level of erosion and the link to the porphyry environment.

The Bi-Se-Te and $\mathrm{Ga}-\mathrm{Ge}-\mathrm{In}$ signature with pronounced Au enrichment is a characteristic feature for IS and HS ore envir Jnment in the southern part of the Panagyurishte ore district suggesting a comparable sources for the epithermal mineralizing fluids.

Bi minerals often occur in close association with gold and chalcopyrite, giving the assemblage significance as potential guide to Au-rich environment. The aikinite derivates are most widespread and persistent minerals in the chalcopyrite-pyrite assemblage and also characteristic for the more deeply eroded hydrothermal systems (Elshitsa).

$\mathrm{Se}$ and Te enrichment is characteristic and most abundant in the main mineral assemblages and have greatest affinity to shallower transitional IS to HS type of epithermal systems (Radka, Krassen). The Bi dominant trace mineralogy is characteristic for the ABCD belt (Cook et al., 2002) and reflects, in particula: in the southern part of the Panagyurishte ore district the, IS to HS type of epithermal environment, suggesting shared magma sources and convergence of the processes in the porphyry-epithermal systems.

As a result of the complex multistage and punctuated hydrothermal process the epithermal deposits of Elshitsa, Radka and Krassen contain $\mathrm{Au}$ and $\mathrm{Ag}$ in various proportions, but also rare $\mathrm{Ge}$, $\mathrm{Ga}, \mathrm{In}, \mathrm{Bi}, \mathrm{Se}, \mathrm{Te}, \mathrm{Sn}, \mathrm{V}$ and $\mathrm{W}$ bearing minerals. The ore remobilization processes facilitate formation of a specific, narrow range of $\mathrm{Se}, \mathrm{Te}, \mathrm{Ga}, \mathrm{Ge}$ and In minerals in the bornite-tennantite and galena-sphalerite-chalcopyrite assemblages in Radka and Krassen epithermal deposits, and corresponds to the increasing role of the $\mathrm{fS}_{2} / \mathrm{fO}_{2}$ control during the transition from IS to $\mathrm{HS}$ environment.

\section{REFERENCES}

Amov B., Bogdanov B. \& Baldjieva T. 1974. Lead isotope composition and some features concerning the genesis and the age of the ore deposits in south Bulgaria. In: Problems of Ore Deposition, Proc 4th IAGOD Symp., vol. 2, 13-25 (in Russian).

Angelkov K. 1974. Ore formation and sulphur isotope composition of the deposits in Panagyurishte ore region (in Russian). In: Problems of Ore Deposition, Proc. 4th IAGOD Symp., 2, 26-33.

Bogdanov B. 1980. Massive sulphide and porphyry-copper deposits in the Panagyurishte district Bulgaria. In: European Copper Depnsits. SGA Spec. Publ., 1, 50-58. 
Bogdanov B. 1984. Hydrothermal systems of massive sulphide, porphyry-copper and vein copper deposits of Sredna Gora zone in Bulgaria. Proc. 6th IAGOD Symp., Stuttgart. 63-67.

Bogdanov B. 1987, The copper deposits in Bulgaria. Technika publ, Sofia. 388p. (in Bulgarian).

Bogdanov K., Tsonev D. \& Kuzmanov K. 1997. Mineralogy of gold in the Elshitsa massive sulphide deposit, Sredna Gora zone, Bulgaria. Mineral. Deposita, 32. 219-229.

Bogdanov K. \& Popov K. 2003. Cu-Au epithermal systems in the southern part of Panagyurishte ore region. Soc. Econ. Geol. Guidebook Series, Vol. 36, 91-114.

Cook N.J., Ciobanu C.L. \& Bogdanov K. 2002. Trace mineralogy of the Upper Cretaceous Banatitic Magmatic and Metallogenic belt, S.E. Europe, 11th IAGOD Symp Geocongr 2002. CD vol. of ex. Abst., Geol. Surv. Namibia.

Dabovski C., Harkovska A., Kamenov B., Mavrudchiev B., Stanisheva-Vassileva G. \& Yanev Y. 1991. A geodynamic model of Alpine magmatism in Bulgaria. Geol. Balc., 21, 4, 3-15.

Dimitrov C. 1960. Magmatismus und Erzbildung im Erzgebeit von Panagjuriste. Freib. Forschung. C79.

Handler R., Velichkova S., Neubauer F. \& Ivanov Z. 2002. Late Cretaceous magmatic and tectonic processes in the Srednogorie zone, Bulgaria: constraints from ${ }^{40} \mathrm{Ar} /{ }^{39} \mathrm{Ar}$ age dating results. GEODE Workshop on Srednogorie. Sofia, April 2002, Abstr. 7.

Hedenquist J.W., Izawa E., Arribas A. \& White N.C. 1996. Epithermal gold deposits: Styles, characteristics, and exploration. Resource Geol Spec Publ No 1, poster and booklet. 17p.

Hedenquist J.W, Arribas A R. \& Gonzalez-Urien E. 2000. Exploration for Epithermal Gold Deposits. In: Rev. in Econ. Geol., Hagemann S.G. \& Brown P.E. eds, Vol. 13, Gold in 2000, 560p.

Heinrich C.A. \& Neubauer F. 2002. Cu - Au - Pb - Zn - Ag metallogeny of the Alpine - Balkan - Carpathian Dinaride geodynamic province. Mineral. Deposita, 37, 533-540.

Jankovic S. 1977. The copper deposits and geotectonic setting of the Tethyan-Eurasian metallogenic belt. Mineral. Deposita, 12, 37-47.

Kouzmanov K. 2001. Genese des concentrations et metaux de base et precieux de Radka et Elshitsa (zone de Sredna Gora, Bulgare): une approche par l'etude mineralogique, isotopique et des inclusions fluids. Ph.D. Thesis, Univ. of Orleans, 437p.

Lilov P. \& Chipchakova S. 1999. K-Ar dating of the Upper Cretaceous magmatic rocks and hydrothermal metasomatic rocks from tra Central Srednogorie. Geochem. Mineral. Petrol. 36, 71-91 (in Bulgarian).

Morrison G.W., Rose W.J. \& Jaireth S. 1991. Geological and geochemical controls on the silver content (fineness) of gold in gold-silver deposits. Ore Geol. Rev., 6, 333-364.

Peycheva I., Von Quadt A., Kamenov B., Ivanov Zh. \& Georgiev N. 2001. New isotope data for Upper Cretaceous magma emplacement in the southern and south-western parts of Central Srednogorie. ABCDGEODE 2001 workshop, Vata Bai, Romania, Abs., Rom. J. Mineral. Depos. 79, Supl. 2, 82-83.

Peycheva I., Von Quadt A., Kouzmanov K. \& Bogdanov K. 2003. Timing of magmatism and mineralisation in Elshitsa and Vlaykov Vrh $\mathrm{Cu}(\mathrm{Au})$ deposits of Central Srednogorie, Bulgaria: constraints from U-Pb zircon and rutile geochronology and $\mathrm{Hf}$-zircon and $\mathrm{Sr}$ whole-rock tracing. ABCD-GEODE 2003 workshop, Seggauberg, Austria, Abs., 46.

Popov P., Strashimirov S. \& Popov K. 2000. Geology and metallogeny of the Srednogorie zone and Panagyurishte ore region. Soc. Econ. Geol. Guidebook Series, Vol.36, 7-25

Radonova T. \& Velinov I. 1974. Relationships between propylites and secondary quartzites with the ore mineralizations in the Central and Western Srednogorie (Bulgaria). In: Metasomatism and Ore Formation, Nauka, Moscow, 60-69. (in Russian).

Sillitoe R.H. 1999. VMS and porphyry copper deposits: Products of discrete tectono-magmatic settings. In: Mineral Deposits: Process to Processing, Stanley, C.J. et al. eds. Balkema, Rotterdam, 7-10.

Sillitoe R.H., Hannington M.D., Thompson J.F.H. 1996. High sulphidation deposits in the volcanogenic massive sulphide environment. Econ. Geol. 91, 204-212

Strashimirov. S. \& Popov P. 2000. Geology and metallogeny of the Panagyurishte ore region (Srednogorie zone, Bulgaria). GEODE 2000 Workshop, Guide to excursions A and C, Sofia, 50p.

Strashimirov S., Petrunov R. \& Kanazirski M. 2002. Porphyry-copper mineralisation in the central Srednogorie zone, Bulgaria. Mineral. Deposita, 37, 587-598.

Tarkian M., Hünken U., Tokmakchieva M. \& Bogdanov K. 2003. Precious-metal distribution and fluid-inclusion petrography of the Elatsite porphyry copper deposit, Bulgaria. Minera. Deposita, 38, 261-281.

Todorov T. 1991. NAA analysis of gold in minerals from Upper Cretaceous massive copper deposits in Bulgaria. Terra Nova, 3, 311-316.

Tsonev D. 1974. Evolution of the mineral parageneses in the Radka and Elshitsa cupriferous-pyritic deposits, Panagyurishte ore district, Bulgaria. In: Bogdanov (ed) Problems of Ore Deposition, Proc. 4th IAGOD Symp, v. 2, 327-333.

Velinov I., Loginov V., Nosik L., Radonova T. \& Rusinov V. 1978. Genetical features of the massive sulphide deposits from the Srednogorie zone of Bulgaria and Jugoslavia. In: Metasomatism and Ore Deposition. Nauka, Moscow, 176-133. (in Russian). 